Katharina Gerund

\title{
Militärische ,Para(llel)gesellschaft(en)‘? Die Soldatenfrau als Vermittlerin und Grenzgängerin in der amerikanischen Populärkultur des 21. Jahrhunderts
}

\section{Einleitung}

Mit der Abschaffung der Wehrpflicht in den USA im Kontext der Proteste gegen den Vietnamkrieg wurde nicht nur das US-Militär stärker professionalisiert, es entwickelte sich auch eine scheinbar zunehmende Kluft zwischen der Zivilgesellschaft und den militärischen Gemeinschaften. Konnte zuvor noch - zumindest in der Theorie - nahezu jede amerikanische Familie von den Kriegseinsätzen der USA unmittelbar betroffen sein, sind es heute weniger als ein Prozent der Bevölkerung, welche direkt in die militärischen Aktivitäten eingebunden sind und die Auswirkungen der US-amerikanischen Kriege in ihrem Alltag erfahren. Besonders deutlich wird diese Entwicklung im Nachgang der Terroranschläge von 9/11 und im Rahmen des auf Dauer gestellten Ausnahmezustand eines sog. Global War on Terror mitsamt den wiederholten Kriegseinsätzen in Irak und Afghanistan. ${ }^{1}$ Aber auch schon vor dieser Entwicklung konnte das amerikanische Militär in mehrerlei Hinsicht als eine Art ,Parallelgesellschaft“ verstanden werden, also als eine „Gesellschaft in der Gesellschaft“ - mit eigenen „Werte[n], Normen und Haltungen“ (die allerdings nicht zwingend signifikant „,vom Konsens einer ,Mehrheitsgesellschaft" divergieren) und einer klar markierten Abgrenzung zur Zivilgesellschaft zumindest in kultureller und institutioneller Hinsicht, die sich zum Beispiel in der Sprache, einem spezifischen Verhaltenskodex oder einer eigenen Gerichtsbarkeit zeigt (Hiergeist 2017, 9). Militärische Basen und Stützpunkte sind - innerhalb und außerhalb der USA - zudem territorial klar abgegrenzt und von den jeweiligen Zivilgesellschaften zumindest ein Stück weit abgeschottet. Damit erfüllen sie nur bedingt die Kriterien einer idealtypischen ,Parallelgesellschaft‘, dennoch werden mit diesem „schillernd[en]“ Begriff (Meyer 2002, 195) die ambivalenten und

1 Die Diskussion um das Verhältnis zwischen US-amerikanischem Militär und Zivilbevölkerung ist nicht an sich neu - ,the long-standing debate about the idea of a civil-military ,gap“ in American society [...] is as old as the American republic itself“ (Golby et al. 2016, 97). Dennoch lässt sich argumentieren, dass mit den Folgen von 9/11 zumindest eine Neuverhandlung zu beobachten ist (vgl. etwa Owens 2016, 72-73; Golby et al. 2016, 98-99).

Ә Open Access. (C) 2021 Katharina Gerund, publiziert von De Gruyter. (c) BY-NC-ND Dieses Werk ist lizenziert unter einer Creative Commons Namensnennung - Nicht-kommerziell - Keine Bearbeitung 4.0 International Lizenz. https://doi.org/10.1515/9783110707489-005 
vielfältigen Effekte der Abgrenzung von der Zivilgesellschaft angedeutet - vom möglichen Beitrag zu „Persönlichkeitsstabilisierung“ (Micus und Walter 2006) und einem „sense of belonging“ (Gomes 2020, xv) über einen Beitrag zu Integration und gesellschaftlichem Wandel bis hin zu Segregation, Entfremdung und der letztlich substantiellen Gefahr für einen normativen Konsens der ,Mehrheitsgesellschaft‘. Das US-amerikanische Militär etwa stellt Einwanderergruppierungen und unterdrückten ,Minderheiten' den Zugang zur Staatsbürgerschaft über die Beteiligung am nationalen Kriegseinsatz zumindest in Aussicht (vgl. z. B. Aptekar 2015; Cowen und Gilbert 2008; Takaki 2000), gleichzeitig trägt es auch zu einer Militarisierung der US-amerikanischen Gesellschaft (und der Welt) bei (vgl. z. B. Enloe 2000 und 2016; González et al. 2019). Bereits 1997 konstatiert Thomas Ricks im Magazin The Atlantic Monthly die Gefahr einer ,parallelen` Gesellschaftsstruktur und Subkultur im US-Militär:

It now appears not only possible but likely that over the next twenty years the U.S. military will revert to a kind of garrison status, largely self-contained and increasingly distinct as a society and subculture. „Today,“ says retired Admiral Stanley Arthur, who commanded U.S. naval forces during the Gulf War, ,the armed forces are no longer representative of the people they serve. More and more, enlisted [men and women] as well as officers are beginning to feel that they are special, better than the society they serve. This is not healthy in an armed force serving a democracy.“

(Ricks 1997)

Jim Mattis und Kori Schake sehen 2016 nach jüngeren Umfrageergebnissen zwar keine besorgniserregende Entfremdung des Militärs von der amerikanischen Zivilgesellschaft, aber dennoch konstatieren auch sie „many gaps between the American public and its military“ (4). Das Militär hat zwar in der Bevölkerung an Rückhalt gewonnen, aber die Amerikaner`innen wissen weniger denn je über ihre ,Truppen“ (vgl. Brooks 2016, 21). Rosa Brooks erklärt: „though support for ,the troops" has become a kind of American civil religion, these ritualized gestures sometimes seem only to emphasize the distance between the military and civilian society“ (Brooks 2016, 22). Denn tatsächlich sehen große Teile der Amerikaner`innen starke kulturelle Differenzen zwischen dem Militär und ihrer eigenen Lebenswirklichkeit und auch eine substantielle Mehrheit der aktiven Militärangehörigen und Reservist`innen erkennen wenig Gemeinsamkeiten zwischen ihrer Gemeinschaft und der Zivilbevölkerung (vgl. Brooks 2016, 23-24). ${ }^{2}$ Trotz des vielfach konstatierten „familiarity gap“ (vgl. Golby et al. 2016, 102), das sich unterschiedlich interpretieren und bewerten lässt, steht das Militär in (popu-

2 Benjamin Wittes und Cody Poplin haben dazu weiterführend argumentiert, dass es sich bei dieser Entfremdung um eine einseitige Entwicklung handelt: „Note that civilian-military isolation is largely a one-way street. Members of the military interact all the time with civilian society, after all“ (Poplin und Wittes 2016, 148). 
lär)kulturellen Repräsentationen stellvertretend für die „imagined community“ (vgl. Anderson 1983) der Nation und wird teils sogar als das ,bessere“ Amerika inszeniert, in dem sich die grundlegenden Werte und Ideale der USA besonders deutlich zeigen - etwa mit Blick auf Chancengleichheit und (soziale) Aufstiegsmöglichkeiten, auf das scheinbar meritokratische System oder auf eine gemeinsame Identität und Loyalität jenseits etablierter Differenzkategorien. Es kann in diesem Sinne als ,Paragesellschaft' verstanden werden, die sich zwar nachdrücklich von der zivilen Gesellschaft abgrenzt, sich aber nicht primär auf ein ,alternatives' Wertesystem beruft, sondern als mustergültiger Inbegriff US-amerikanischer Ideale inszeniert. Die zunehmende geographische, politische und kulturelle Isolation des Militärs und das geringe Wissen über die militärische Kultur und Lebensrealität in der Bevölkerung erfordern zudem verstärkt Übersetzungsleistungen, um eine Verständigung zwischen Zivilgesellschaft und militärischen Institutionen zu ermöglichen. Die Ehepartner*innen der Soldat*innen nehmen im 21. Jahrhundert als Grenzgänger*innen zwischen Militärkultur und Zivilgesellschaft folglich eine Schlüsselrolle ein. Als Zivilist*innen sind sie zwar formal keine Angehörigen des Militärs, als Angehörige eines/einer Soldat*in sind sie dennoch mit der militärischen Kultur und Gemeinschaft vertraut und in diese integriert. Die Soldatenfrauen $^{3}$ äußern sich nicht nur öffentlich zu ihrer Kriegserfahrung an der Heimatfront, sondern nehmen eine wichtige symbolische Rolle im kulturellen Imaginären der USA ein. In den Medien sieht man sie häufig als passive Figuren bei politischen Veranstaltungen, bei kulturellen Events oder militärischen Ereignissen wie der Verabschiedung oder Willkommenszeremonie für Soldaten. In zahlreichen kulturellen Texten aus den vergangenen zwei Dekaden übernehmen sie die wichtige Mittlerfunktion, den Rezipient^innen die Kriegseinsätze im Rahmen des Global War on Terror zu plausibilieren sowie Einblicke in das militärische Alltagsleben zu geben, das als konstanten Ausnahmezustand inszeniert wird, und um Verständnis für ihre Situation zu werben. Magazine wie Military Spouse, fiktionale Texte wie Siobhan Fallons Kurzgeschichten You Know When the Men Are Gone (2011) oder Jehanne Dubrows Gedichtband Stateside: Poems (2009) und Autobiographien wie Taya Kyles American Wife: Love, War, Faith, and Renewal (mit JimDeFelice, 2015), Vicki Codys Army Wife: A Story of Love and Family in the Heart of the Army (2016) oder Kristine Schellhaas' 15 Years of War: How the Longest War in U.S. History Affected a Military Family in Love, Loss, and the Cost of Service (2016) erlauben nicht nur eine Selbstverständigung über die Rolle und Bedeutung von

3 Military Spouses werden trotz sich wandelnder Familienkonstellationen nach wie vor primär als Frauen imaginiert und es sind vor allem Frauen, die sich öffentlich in dieser Rolle Gehör verschaffen. 
Soldatenfrauen. Sie übernehmen auch Kontrolle über ihre öffentliche Darstellung, verschaffen den Frauen eine Stimme im Diskurs um die sog. ,endlosen` Kriege der USA und leisten relevante „affektive Arbeit“ ${ }^{\star 4}$ hinsichtlich der öffentlichen Meinung und „öffentlichen Gefühle“ in Bezug auf die Kriege im Irak und in Afghanistan in der amerikanischen Gesellschaft. Ihre Darstellungen rekurrieren dabei häufig auf Formen impliziten Wissens (insbesondere emotionales Wissen und Körperwissen), um sich zu autorisieren. Sie generieren „affective agency“ ${ }^{\text {5 }}$ für die Soldatenfrauen und Unterstützung für das Militär - und damit auch in gewissem Umfang für die amerikanischen Kriege. Oft sind sie - freiwillig oder unfreiwillig - Teil der Kriegspropaganda. Texte von und über Soldatenfrauen dienen aber nicht nur der Selbstverständigung untereinander, sondern richten sich auch an ein breites Publikum. Dieses wird einerseits ein Stück weit eingeführt in die Parallelwelt des Militärs, anderseits auch immer wieder daran erinnert, dass es letztlich unmöglich ist, die Kriegserfahrungen nachzuvollziehen, sofern man diese nicht selbst gemacht hat. Zudem werden nur sehr ausgewählte Informationen über den militärisch-industriellen Komplex und die Kriegseinsätze der USA mit dem Publikum geteilt. Die Protagonistinnen weisen in der Regel nicht nur explizit darauf hin, dass sie über viele Aktivitäten ihrer Männer im Unklaren sind und dieses NichtWissen im Interesse der nationalen Sicherheit akzeptieren, da sie den Soldaten und den militärischen Institutionen vertrauen (müssen), sondern fordern auch ihr Publikum zumindest implizit auf, es ihnen gleichzutun. Sie propagieren und normalisieren damit, dass, wie Timothy Melley schreibt, „unknowing is essential to modern citizenship“ (Melley 2015, 17). Im Folgenden analysiere ich diese Dynamik anhand von zwei Beispielen der Fremd- und Selbstrepräsentation von Soldatenfrauen - der CBS-Fernsehserie The Unit (2006-2009) und der Autobiographie I Love a Man in Uniform: A Memoir of Love, War, and Other Battles (2009) von Lily Burana. Diese Artefakte inszenieren aus unterschiedlichen Perspektiven und in verschiedenen medialen Registern die Soldatenfrau als Grenzgängerin sowie als Vermittlerin zwischen Zivilgesellschaft und Militärkultur. Sie lassen sich zwar als kritische Auseinandersetzung mit den amerikanischen Kriegen wie auch dem US-Militär lesen, dennoch machen sie sich die Konstruktion des Militärs als ,Paragesellschaft' ebenso wie das emotionale und verkörperte Wissen über die Kriegserfahrung an der Heimatfront zu Nutze, um den/die unwissende/n Bürger`in

\footnotetext{
4 Der Begriff wird hier im Sinne von Michael Hardt und Antonio Negri übernommen. Sie definieren „affective labor“ als „labor that produces or manipulates affects“ (Hardt und Negri 2004, 108).

5 Den Begriff der ,affective agency übernehme ich von Rebecca Wanzo, die darunter Folgendes versteht: „the ability of a subject to have her political and social circumstances move a populace and produce institutional effects“ (Wanzo 2009, 3).
} 
in seiner/ihrer Ignoranz zu bestätigen, um seine/ihre Unterstützung für das Militär zu werben und sein/ihr Vertrauen in den Nationalstaat und seine institutionellen Akteure zu bekräftigen.

\section{Vom „Anarchy Girl“ zur Offiziersgattin: Lily Buranas I Love a Man in Uniform}

Lily Burana war bereits eine profilierte Journalistin und Autorin, als sie 2009 I Love a Man in Uniform: A Memoir of Love, War, and Other Battles veröffentlichte. 2001 war ihr erstes autobiografisches Buch unter dem Titel Strip City: A Stripper's Farewell Journey Across America erschienen, das Zuspruch auch unter Kritiker*innen fand. In I Love a Man in Uniform beschreibt Burana sich selbst nicht nur als ehemalige Stripperin, sondern auch als anti-autoritär, als Rebellin und als „accidental teenage communist“ (vgl. 15-18, 34) und konstatiert: „I never thought I would say yes to a date with an Army man; it was an utter impossibility“ (2009, 14). Im Folgenden erzählt sie ebenso humorvoll wie assoziationsreich von ihrer unwahrscheinlichen Romanze mit einem Soldaten, von ihrer übereilten Hochzeit als „War on Terror bride“ (Burana 2009, 53) und ihrem Leben als Offiziersgattin, deren Mann im Irakkrieg dient und an der Militärakademie West Point tätig ist. Die metaphorische und semantische Überlagerung der persönlichen Liebesbeziehung mit der US-amerikanischen Kriegspolitik ist bereits im Titel angelegt und hat im Laufe der autobiografischen Erzählung mehrere Funktionen. Sie emotionalisiert das Kriegsgeschehen durch die (limitierte) Perspektive der Soldatenfrau und transponiert die globalen Ereignisse des Global War on Terror auf die Heimatfront und häusliche Sphäre; sie markiert die Militarisierung des Lebens der Protagonistin und ihrer romantischen Beziehung als notwendige Normalität im Kontext des Krieges; und sie verwischt die Grenze zwischen einer vermeintlich privaten Sphäre familialer Bindungen und dem öffentlichen Diskurs um die Außen- und Innenpolitik der USA im Nachgang der Terroranschläge vom 11. September 2001. Gleichzeitig zieht der Text eine klare Trennlinie zwischen den parallelen Welten der militärischen Gemeinschaft und der Zivilbevölkerung. Bereits zu Beginn erklärt Burana: „[T]here’s a Green Curtain rule in effect when it comes to communicating about the military with people who are strangers to that world“ (2009, 4). Während ihr Buch einerseits einen teilweisen Bruch mit dieser Regel und einen persönlichen Einblick in ihr Leben mit dem Militär verspricht, erinnert es die Lesenden doch immer wieder an die Limitierungen ihrer Einsichten in die militärische Kultur und Lebensrealität. Buranas Text basiert auf der Prämisse, dass es im professionellen Leben ihres Man- 
nes ebenso wie in der US-amerikanischen Kriegsführung Aspekte gibt, die weder sie noch ihre Lesenden wissen sollten oder verstehen könnten. Er perpetuiert dabei auch eine vergeschlechtlichte Logik des Krieges als männlich kodiert im Kontrast zur feminin dominierten Heimatfront:

I never asked Mike about anything he'd seen in combat [...]. I didn't feel it was within my rights to press him for details, and womanly intuition guided me to soothe rather than pry. [...] He was part of a world that I could not - and likely would not - ever know.

(Burana 2009, 63)

Trotz und gerade wegen dieser Einschränkung ist Burana als Zivilistin, als frischgebackene Ehefrau eines Offiziers und als Novizin in der militärischen Gemeinschaft in einer idealen Position, um ihren Lesenden militärisches Protokoll, Sprache und alltägliches Leben zu erklären und ,uns` in die ,Parallelwelt' des amerikanischen Militärs mitzunehmen. Dies zeigt sich etwa zu Beginn des zweiten Kapitels „Simple as Alpha Bravo Charlie“, in dem das Phänomen des „Greenspeak“ verhandelt wird (vgl. Burana 2009, insbes. 22-24), in der in den Text integrierten ,dictionary definition of hooah“ (31-32) oder auch in den zahlreichen Erklärungen von Akronymen und (militärischen) Regularien (vgl. z. B. 55, 106-107, 124, 137, 145, 208, 232). Immer wieder betont sie, wie unwahrscheinlich es gewesen sei, dass sie in dieser ,Paragesellschaft‘ ihren Platz finden würde. Mittels dieser Erzählstrategie suggeriert der Text, dass auch die Lesenden ihre Vorbehalte gegen das Militär überwinden können, wenn selbst „Anarchy Girl“ (Burana 2009, 2) dazu imstande war. Dieser Effekt wird durch die ironische Einfärbung des Textes und deren Distanzierungsleistung noch verstärkt. Aus ihrer kritischen Haltung zum Global War on Terror, zum militärischen Protokoll und insbesondere zur idealisierten Rolle der Soldatenfrau macht Burana dann auch in ihrem Buch keinen Hehl:

I was supposed to be the suffering Saint Wifey, crying while I adjusted the yellow ribbons on the tree, and instead I was rolling my eyes all the time.

$(2009,83)^{6}$

I married into the military-industrial complex, yes, yet I reserved the right to judge. Love is tolerant; it is not at all blind.

$(2009,89)$

Als sie vom Abu Ghraib-Skandal erfährt, sei sie auf eine kaum vorstellbare Art und Weise aufgebracht gewesen. Für ihre Lesenden versucht sie diese Erfahrung durch folgende Analogie - die erneut die affektiven Logiken romantischer Beziehungen mit der Rolle des US-Militärs und seinen kriegerischen Handlungen verquickt - nachvollziehbar zu machen: „If you've ever had someone cheat

6 Dennoch nutzt Burana in ihren Memoiren die Darstellung von Tränen, emotionalem Exzess und Verzweiflung für ihre Zwecke (vgl. 2009, z. B. 95; 97). 
on you - the feeling was the same“ (Burana 2009, 297). Dieser Vergleich markiert zwar die Ereignisse in Abu Ghraib als moralische Transgression und Vertrauensbruch, aber er trivialisiert sie auch in signifikanter Weise. Die Lesenden werden angehalten, sich mit der schockierten Soldatenfrau und ihrem Gefühl von Enttäuschung und Betrug zu identifizieren, anstatt beispielsweise mit den gefolterten und getöteten Opfern der Soldaten. Deren Leben sind in dieser Logik jenseits dessen, was Judith Butler als „grievability“7 ${ }^{\text {“7 }}$ bezeichnet, vielmehr steht das „precarious life“8 ${ }^{\text {“8 }}$ der Soldatenfrau im Zentrum des Interesses. Buranas „visceral, gut-felt battle between the culture into which I married and the ideals that I hold dear“ (2009, 312) zeigt dann auch für die Lesenden beispielhaft einen versöhnlichen Ausweg auf:

I knew that if I were to ever reconcile the horrors of war and military corruption with the goodness of my marriage - and the military itself - I would have to go beyond Rumsfeld's smarmy advice to overlook the 'few bad apples' and work the grid in reverse: For every crooked soldier, there are hundreds of thousands more who are honorable; for every hurtful military tactic and policy, there are scores more that help.

(Burana 2009, 309)

Unabhängig von der persönlichen Haltung zum Krieg, so suggeriert der Text, ist das Militär also zu unterstützen. Trotz verschiedener Probleme - inklusive einer zeitweisen Trennung von ihrem Mann und dem Kampf gegen PTSD (hier u. a. interpretiert als „post-traumatic spouse disorder“, Burana 2009, 287) - findet Burana schließlich ihren Platz in der militärischen Gemeinschaft. Ihre Vergangenheit als Stripperin und ihre neue Rolle als Offiziersgattin kann sie in Einklang bringen, indem sie einen Burlesque-Kurs für Soldatenfrauen mit dem Titel „Operation Bombshell“ (Burana 2009, 328) ins Leben ruft. ${ }^{9}$ Sie hat gelernt, dass die Rolle der Soldatenfrau ein spezifisches emotionales und verkörpertes Wissen erfordert:

7 ,Grievability“ nach Judith Butler „,is a presupposition for the life that matters“ (Butler 2010, 14). Butler erläutert weiter: „whose life, if extinguished, would be publicly grievable and whose life would leave either no public trace to grieve, or only a partial, mangled, and enigmatic trace“ (Butler 2010, 75).

8 Butler erklärt hierzu: „To say that life is precarious is to say that the possibility of being sustained relies fundamentally on social and political conditions, and not only on a postulated internal drive to live“ (Butler 2010, 21).

9 Sie beschreibt diesen Prozess so: „I'd kept those two parts of my self completely separate the wife and the wild girls - as if they might contaminate each other. How nice it was to finally accept that, instead, they complemented each other. I could knit these two halves together, then give them as a gift to other women: Have fun. Be glamorous. Be free. Be yourself. Enjoy“ (Burana 2009, 334). 
[M]ilitary-wife life meant painting with a new emotional palette.

(Burana 2009, 119)

[T] here was much more to being a military wife than courtesies and customs and regulations - things I couldn't learn by simply putting my nose in a book.

(Burana 2009, 124)

Letztlich beherrscht sie nicht nur die unausgesprochenen Regeln, die es als Offiziersgattin einzuhalten gilt (Burana 2009, 329), sondern hat sich auch mit den Prozessen und Protokollen von Nicht-Wissen und (Ver-)Schweigen angefreundet:

No one discussed the war. [...] Among the wives, we talked about where the war had taken our husbands, what it was doing to our families, our plans, our careers, our dreams, our psyches, our souls, and our marriages. [...] I understood the silence as an extension of the soldiers' own protocol. [...] So the glue that binds the Army community is common experience rather than shared opinion.

(Burana 2009, 154-155)

Diese geteilte Erfahrung ist für Außenstehende kaum nachzuvollziehen. Burana beschreibt nicht nur die Entfremdung von ihren Freund`innen, die keine Beziehung zum Militär haben, sondern auch, wie wenig Zivilist`innen allgemein von der Realität des Krieges und den Erfahrungen der Soldat*innen und ihren Angehörigen nachvollziehen können:

[...] when some well-meaning civilian, a neighbor or someone at the gym, would say, 'I know how you feel,' I'd be so pissed, I was sure my brain would melt and pour out of my eyes. No, you most certainly damn don’t know how I feel. (Burana 2009, 86, Herv. i. O.)

I Love a Man in Uniform vermittelt im buchstäblichen und metaphorischen Sinne zwischen Militärkultur und Zivilgesellschaft und sensibilisiert für die Situation der Soldatenfrauen und deren Leid (,the pain of those at home who hurt by proxy,“ 287; „The Army asks a lot of its families,“ 340). Zugleich weist der Text auch die Grenzen dieser Übersetzungsleistung auf, indem er immer wieder auf die spezifischen Erfahrungen von Soldatenfrauen rekurriert, die sich dem Verständnis Außenstehender entziehen.

\section{Secrecy and Silence: Die militärische ,Parallelwelt' in The Unit}

Die Fernsehserie The Unit basiert lose auf Eric Haneys Autobiografie Inside Delta Force: The Story of America's Elite Counterterrorist Unit und wurde von 2006 bis 2009 in vier Staffeln auf CBS ausgestrahlt. Die Drama- und Actionserie folgt einer fiktionalen Spezialeinheit der Delta Force bei ihren Einsätzen zur Terrorbekämpfung an verschiedenen Orten der Welt. Parallel zeigt sie auch die Ereignisse auf 
der Militärbasis und insbesondere im Leben der Soldatenfrauen. Auch hier geht es um die spezifische Situation in den USA nach 9/11 - der dauerhafte Ausnahmezustand sowie die Normalisierung und Legitimierung von militärischen Interventionen, Folter und präventiven Erstschlägen sind in der Serie allgegenwärtig. Dennoch etabliert der Prolog zu mehreren Folgen der zweiten Staffel eine längere Geschichte der Delta Force, die bereits in den 1970er Jahren als Eliteeinheit zur Terrorismusbekämpfung gegründet wurde, und unterläuft damit auch ein Stück weit die vermeintliche Zäsur durch den 11. September 2001. ${ }^{10}$ In der von PulitzerPreisträger David Mamet kreierten, produzierten und teilweise auch geschriebenen Serie - die vielen schon deshalb als „Prestige TV“ gilt ${ }^{11}$ - folgen die Zuschauenden den Soldaten auf ihren Trainingseinheiten und verschiedenen Missionen. Cynthia Young hat die Serie treffenderweise als „,virtual travelogue of global hotspots China, Afghanistan, Pakistan, Spain, Panama“ bezeichnet und herausgestellt, wie die Serie die globale Vormachtstellung und Omnipotenz der USA imaginiert und dabei von Anbeginn an alle „political or ethical objections“ der Zuschauenden einer solchen Vorstellung gegenüber zu entkräften sucht (Young 2014, 46). Selten bekommen die klandestinen Einsätze eine ausführliche Kontextualisierung und die Zuschauenden erfahren kaum etwas über die politischen Zusammenhänge der Aufträge, welche die Soldaten erhalten und ausführen. Die Soldaten um Jonas Blane (Dennis Haysbert) erfüllen in der Regel ihre Missionen, ohne deren Sinn oder Legitimität weiterführend in Frage zu stellen. Auch hier wird dem Publikum also nahegelegt, sich - wie die fiktionalen Soldaten - mit ihrem limitierten Wissen und Nicht-Wissen zu arrangieren und dieses im Interesse der nationalen Sicherheit zu akzeptieren. Oftmals fokussiert die Serie pro Folge eine Mission, ohne für diese größere narrative Bögen zu spannen - anders sieht es da bei der Darstellung der Entwicklungen in den Familien und im persönlichen Leben der Soldaten aus, die sich über viele Episoden erstrecken und teils komplexe Verflechtungen beinhalten. Mit Bob und Kim Brown (Scott Foley und Audrey Marie Anderson) kommen zu Beginn der Serie auch zwei Neuankömmlinge in die abgeschottete Gemeinschaft der Spezialeinheit, die selbst im US-Militär eine Parallel-Existenz darstellt, und

10 Dieser Prolog lautet: „In 1979, Congress authorized the formation of a contingent of elite Special Forces soldiers who answer only to the President of the United States. Their missions and their very existence are closely guarded secrets protected by the soldiers themselves and their wives, who possess secrets of their own".

11 Dieser Effekt war allerdings nur von kurzer Dauer, wie Jason Mittell erläutert: „It is rare for a writer's track record outside of television to translate into a notable presence in the collaborative realm of television - for instance, after an initial press burst, little of award-winning playwright and filmmaker David Mamet's prestige rubbed off onto the CBS military drama The Unit that he created“ (Mittell 2015, 99). 
fungieren als Mittler^in für die Zuschauenden. Die Soldaten sind Akteure einer militärischen Einheit, die an der Grenze zwischen der offiziellen Institution des US-Militärs und den „para-institutional armed actors“ eines „outsourced empire“ operieren (Thomson 2018, 5). ${ }^{12}$ Die Einheit hat einen eigenen Verhaltens- und Ehrenkodex - die Soldaten, so erklärt Colonel Tom Ryan (Robert Patrick), „answer to a higher code“ („Play 16“ S03 E08). Dieser wird exemplarisch ersichtlich, als seine Affäre mit der Frau eines seiner Soldaten, Mack Gerhardt (Max Martini), bekannt wird und das Team ein Todesurteil fällt (das jedoch letztlich nicht vollstreckt wird; „Into Hell (Part 1)“ S04 E07). Kim ist bereits eine erfahrene Army Wife und kämpft dennoch mit den Regeln, Erwartungen und Anforderungen ihres neuen Lebens. Molly Blane (Regina Taylor), die qua des Status ihres Mannes eine Führungsrolle unter den Frauen einnimmt, klärt Kim gemeinsam mit Tiffy Gerhardt (Abby Brammell) auf:

Molly: "The 303rd Logistical Studies Unit is where your husband works. That is his cover. It is your cover. Other than that, this Unit has no name. Other than that, it doesn't exist. You will live that cover as if your husband's life depended on it. As believe me, it does.”

Tiffy: "Every person who knows one more piece of information, is one more person who could get our husbands killed."

Molly: "You do not tell your mother, your best friend, your priest what your husband does.”

(„First Responders“ S01 E01)

Die Ikonografie der Serie mag auf den ersten Blick eine Action- und Kriegs-Serie versprechen, aber es geht ebenso zentral um die zum Geschehen an den Einsatzorten der Special Forces parallel montierten Erfahrungen der Soldatenfrauen. Durch diese formal-ästhetische Gestaltung unterbrechen sie buchstäblich die Aktivitäten ihrer Männer und bilden nicht nur ihren Rückhalt, verleihen ihnen Legitimität und dienen als moralischer Kompass, sondern bergen auch konstant die Gefahr der Ablenkung und Gefährdung der Missionen und tragen mithin zum Spannungsaufbau bei. „The first rule of a Unit wife. A distracted soldier is a dead soldier“ wird nahezu mantraartig in der Serie wiederholt (z. B. „Into Hell (Part 1)“ S04 E07). Die klare Trennung zwischen der Heimatfront und den Einsatzorten der Soldaten ist für die ersten zwei Staffeln sehr durchgängig inszeniert, in den letzten zwei Staffeln überlagern sich die beiden Sphären zusehends, als die Fami-

12 Thomson erläutert: ,[t]he US delegated central tasks to militias, mercenaries, PMCs, and a variety of similar non-state armed actors throughout the 'War on Terror' and has continued to do so up until the present day“ (Thomson 2018, 4). Er stellt auch heraus, dass dies an und für sich noch kein neues Phänomen ist: „para-institutional armed actors have been increasingly central to US efforts to create and maintain a US-led liberalized order throughout the post-WWII era“ (5). 
lien der Soldaten das Ziel von Angriffen werden („Always Kiss Them Goodbye“ S03 E03 und „Hill 60“ S04 E16), selbst eine neue Identität annehmen und ,undercover“ leben müssen („Sacrifice“ S04 E01) und sogar vom Vorgesetzten ihrer Ehemänner, Colonel Ryan, aktiv in die laufende Mission involviert werden, um ein terroristisches Netzwerk auszuheben („Dancing Lessons“ S04 E05). ${ }^{13}$ Ihre Handlungsmacht, ihr Aktionsradius und ihr Wissensstand bleiben dennoch eher begrenzt und beschränken sich in erster Linie auf das Management des Heims/der Heimatfront. Mary Beth Haralovich konstatiert:

The women at home are expected to be stoic, blindly loyal, and uninformed. Their men
serve on missions so intense that thoughts of home can rarely intrude. The women of The
Unit are not allowed the context [...] for understanding the tactics, strategies, or purpose in
which their men are engaged. In this Ryan-Mamet gritty television show, the men's tough
visceral physicality contrasts with the soft physical and vocal presence of the women. Wo-
man's knowledge is dealt with severely and rigorously suppressed. (Haralovich 2016, 295)

Die Frauen werden als weiblicher Gegenpart an der Heimatfront zur soldatischen Kampfeinheit im Feld dargestellt. Wie auch die Einsatzgruppe um Jonas Blane formen sie eine Gemeinschaft, die Differenzen zu nivellieren scheint, und sie hüten die Geheimnisse ihrer Männer. Wie Lily Burana wissen auch die fiktionalen Ehefrauen in The Unit, dass sie lieber keine weiterführenden Fragen zu den Tätigkeiten ihrer Männer stellen sollten und sie dienen der moralischen Legitimierung der Handlungen der Soldaten. Und auch ihre Probleme werden sichtbar: Die finanziell prekäre Lage der Militärfamilien ist ebenso immer wieder Thema wie häusliche Gewalt und sozialer Druck (vgl. z. B. „200th“ S01 E03 oder „Two Coins“ S02 E18). Ebenso wird klar, dass die Frauen als zivile Grenzgängerinnen im Militär eine prekäre Situation einnehmen, die von ihrem Status als Ehefrau abhängt und sich mit dem Tod ihres Mannes oder auch im Falle einer Scheidung sofort ändern kann (vgl. z. B. „The Kill Zone“ S02 E03). Die Serie macht wiederholt deutlich, dass die Karrieren und das Überleben der Soldaten von der Verschwiegenheit und Compliance ihrer Frauen abhängt. Colonel Ryan erinnert die Frauen mit Nachdruck an ihre Verantwortung und droht ihnen mit schwerwiegenden Konsequenzen:

13 Der Bruch zwischen den Staffeln zeigt sich auch z. B. an der Titelsequenz. Für die ersten beiden gibt das musikalische Thema der Titelsequenz eine militärische Trittfrequenz vor und die Protagonisten werden in ihrer Uniform oder Kampfmontur gezeigt. Für die letzten zwei Staffeln nimmt der Sound eher pop-musikalische Züge an und die Protagonisten werden prominent in Anzügen dargestellt. Auch ihre ambivalente Rolle als Soldaten und Agenten einer offiziell verdeckten Einheit wird darüber noch einmal besonders eindrücklich sichtbar. 
Do you know who's out there in the civilian world right off this base? At the convenience store, at the laundromat? Do you know who your sister-in-law talks to to puff herself up because she knows one too many things? You don't know. And neither do I. And what we have right here, in the last year, these are the photos of 112 men from the special-forces community who have died because somebody knew they were coming. You cannot trust anyone, anyone outside this room. You will get someone killed! Sleeping on guard, drunk on guard, consorting with the enemy. You run your mouths off on the street, you're no better than that. And, I find out that you're doing it, I will ruin you. [...]. I want the women of this unit so paranoid that you will think twice before you volunteer a nice day to anyone outside this room. It falls on you. You do your job!

(,Security“ S01 E06)

Und seine Frau Charlotte Ryan (Rebecca Pidgeon) erklärt bei ihrer Hochzeitsfeier:

We all have secrets. Most secrets are not shameful. They're just private. The secrets of marriage are private. The secrets of combat are private. We women can't know them. We can only be close to them in being close to you. And as in marriage, you men honor us by trusting us not only to keep your secrets but to respect them.

(„The Wall“ S01 E13)

Die Soldatenfrauen sind also ebenfalls für die nationale Sicherheit verantwortlich und bieten auch für die Zuschauenden ein Verhaltensmodell im Angesicht der globalen Konflikte und terroristischen Bedrohungen. Dies wird besonders deutlich, als in den letzten Staffeln Heimatfront und Kampfzone zunehmend verschmelzen, oder in Sequenzen, in denen sich die Serie explizit mit AntiKriegsprotesten auseinandersetzt. Tiffy z. B. stürmt ein Antikriegs-Treffen unter der Leitung von Wilson James (Jon Hamm), um seine Gruppe - und die Zuschauenden - davon zu überzeugen, dass sie nicht gegen das Militär protestieren können: „And how can you stand there with your superior wisdom and berate the men and women who have sworn with their lives to defend you? You scream at firemen when they're going to put out a fire? Do you? Well, there's a fire, people. You're at war“ („Old Home Week“ S02 E06). Sie gewinnt nicht nur nach Wilsons Einschätzung die Debatte („Old Home Week“ S02 E06), sondern leistet auch ihre Sozialstunden als Freiwillige in der Rechtsberatung des selbstdeklarierten „lefty“ („Bait“ S02 E10). Auch hier sehen wir die Soldatenfrau in einer Mittlerrolle zwischen dem Militär und einer (kriegsmüden und/oder kriegskritischen) Zivilgesellschaft. Die Figuren an der Heimatfront zeichnen sich durch eine unhinterfragte Loyalität ihren Soldaten gegenüber aus, die sich auch durch eine teils durchaus kritische Perspektive auf das Militär nicht erschüttern lässt. ${ }^{14}$ Die Einblicke in das militärische Alltagsleben, das geprägt ist vom Primat der nationalen Sicherheit sowie von notwendiger Abschottung, sind auch in dieser fiktionalen Darstellung

14 Als ihre Tochter mit dem Gedanken spielt, ebenfalls zum Militär zu gehen, ist Molly Blane wenig begeistert und erklärt ihr nüchtern: „There is discrimination against women. There's mud and dirt. There’s rape, there’s war“ („Non-Permissive Environment“ S01 E05). 
limitiert. In der Akzeptanz von Nicht-Wissen, dem Vertrauen in die Institution des Militärs (repräsentiert durch die Soldaten der Spezialeinheit, von denen die meisten auch als Ehemänner und Väter gezeigt werden und dadurch an Tiefe und moralischer Legitimität gewinnen) und der Notwendigkeit zur Verschwiegenheit legt die Serie ein solches Verhalten auch ihren Zuschauenden nahe und die Soldatenfrau wird als Grenzgängerin und Vermittlerin zwischen Zivilgesellschaft und Militär u. a. auch Teil der Kriegspropaganda.

\section{Fazit}

Die Debatte um die weitreichende Ignoranz der amerikanischen Bürger^innen hinsichtlich des US-Militärs, seiner Kultur und seiner konkreten Aktivitäten sowie der Gefahr einer Entwicklung paralleler Welten hat sich im Nachgang der Ereignisse vom 11. September 2001 und dem sog. Global War on Terror noch einmal neu akzentuiert. Gleichzeitig haben Soldatenfrauen ihre symbolische Rolle im kulturellen Imaginären der USA verstärkt aktiv angenommen und ihre Bedeutung für die US-Kriege im 21. Jahrhundert dokumentiert. Die hier exemplarisch analysierten Beispiele zeigen, wie Selbst- und Fremdrepräsentationen die Soldatenfrau als Grenzgängerin zwischen Militärkultur und Zivilbevölkerung inszenieren, die vermitteln und um Unterstützung für das Militär (und indirekt auch dessen Kriegseinsätze) werben kann. Literarische und kulturelle Repräsentationen von ,Para(llel)gesellschaften“ bieten folglich nicht nur spezifische „Positionierungen zu den dargestellten Werte- und Verhaltensweisen der ,Mehrheitsgesellschaft““, sondern haben oft eine „didaktische Funktion“ (Hiergeist 2017, 16). In den hier untersuchten medialen Inszenierungen wird den Lesenden und Zuschauenden eine bestimmte Haltung gegenüber dem Militär nahegelegt. Einerseits werden ihnen Einblicke in diese ,fremde‘ Kultur versprochen und gewährt, für die insbesondere die Figuren der Neuankömmlinge relevant sind, da sie sich als „Mediatorenfiguren“ (Hiergeist 2017, 19) gemeinsam mit dem Publikum die Regeln, Kontexte und Logiken des ,neuen“ Umfelds erschließen. Sie nutzen dazu Authentifizierungsstrategien wie etwa persönliche Erfahrungen (Lily Burana) oder die Beteiligung von Expertinnen an der Produktion fiktionaler Formate (Eric Haney bei The Unit). Andererseits zementieren die Texte damit auch die Grenze zwischen Zivilgesellschaft und Militärkultur, da sie häufig betonen, dass die Erfahrung des Lebens in und mit dem Militär nicht für Außenstehende nachvollziehbar gemacht werden könne und schon aus Sicherheitsgründen viele Aspekte des nationalstaatlichen militärischen Handelns sowie der konkreten Aktivitäten der Soldat*innen geheim 
bleiben müssten. Die Affirmation dieser Grenze bestärkt die einzigartige Bedeutung der Soldatenfrau als liminaler Figur. Die militärische Gemeinschaft definiert sich in den populärkulturellen Darstellungen über geteilte Geheimnisse, gemeinsame Erfahrungen und implizites Wissen sowie über die geographische Nähe auf der Militärbase oder -akademie und deren eigenen expliziten und impliziten Regeln, Traditionen, sprachliche Wendungen und sozio-kulturellen Strukturen. Mithilfe verschiedener erzählerischer Mittel und argumentativer Strategien wird zudem die ,Paragesellschaft‘ des Militärs zum ,besseren` Amerika und somit zum Idealbild der dominanten Gesellschaft stilisiert. Die Texte appellieren an ihr Publikum, die Grenzen ihres Wissens im Interesse der nationalen Sicherheit zu akzeptieren und wenn schon nicht dem Staat selbst, dann doch zumindest den durch ihre Frauen als ,gute“ Ehemänner und ,gute“ Menschen legitimierten Soldaten sowie deren Handeln zu vertrauen. Die Soldatenfrau ist in diesem Sinne der Dreh- und Angelpunkt eines ,agnotologischen“ Diskurses (vgl. Proctor und Schiebinger 2008), dessen didaktisches Potenzial - ganz im Gegensatz zu der augenscheinlichen Agenda der Texte, auf verschiedenen Ebenen Einblicke in das militärische Leben zu gewähren - auf die Verhinderung von Wissen und Wissenserwerb und die Beförderung von Ignoranz abzielt.

\section{Bibliographie}

Anderson, Benedict. Imagined Communities: Reflections on the Origin and Spread of Nationalism. London: Verso, 2006 [1983].

Aptekar, Sofya. The Road to Citizenship: What Naturalization Means for Immigrants and the United States. New Brunswick: Rutgers UP, 2015.

Brooks, Rosa. „Civil-Military Paradoxes“. Warriors \& Citizens: American Views of Our Military. Hg. Kori Schake und Jim Mattis. Stanford: Hoover Institution Press, 2016. 21-68.

Burana, Lily. I Love a Man in Uniform: A Memoir of Love, War, and Other Battles. New York: Weinstein Books, 2009.

Butler, Judith. Frames of War: When Is Life Grievable? London: Verso, 2010.

Cowen, Deborah und Emily Gilbert (Hg.). War, Citizenship, Territory. New York: Routledge, 2008.

Enloe, Cynthia. Maneuvers: The International Politics of Militarizing Women's Lives. Berkeley: University of California Press, 2000.

Enloe, Cynthia. Globalization and Militarism: Feminists Make the Link. Lanham: Rowman \& Littlefield, 2016.

Golby, Jim, Lindsay P. Cohn und Peter D. Feaver. „Thanks for Your Service: Civilian and Veteran Attitudes after Fifteen Years of War". Warriors \& Citizens: American Views of Our Military. Hg. Kori Schake und Jim Mattis. Stanford: Hoover Institution Press, 2016. 97-142.

Gomes, Catherine. „Living in a Parallel Society: International Students and Their Friendship Circles“. Journal of International Students 10.1 (2020): xiii-xv. 
González, Robert J., Hugh Gusterson und Gustaaf Houtman (Hg.). Militarization: A Reader. Durham: Duke University Press, 2019.

Haney, Eric L. Inside Delta Force: The Story of America's Elite Counterterrorist Unit. New York: Delacorte Press, 2002.

Haralovich, Mary Elizabeth. „Those at Home Also Serve: Women's Television and Embedded Military Realism in Army Wives (2006-2014)“. A Companion to the War Film. Hg. Douglas

A. Cunnigham und John C. Nelson. West Sussex: Wiley Blackwell, 2016. 289-304.

Hardt, Michael und Antonio Negri. Multitude: War and Democracy in the Age of Empire. London: Penguin, 2004.

Hiergeist, Teresa. „Selbst, anders, neu. Reflexionen zu den kulturellen und ästhetischen Bedeutungen von ,Parallel- und Alternativgesellschaften'“. Parallel- und Alternativgesellschaften in den Gegenwartsliteraturen. Hg. Teresa Hiergeist. Würzburg: Königshausen \& Neumann, 2017. 7-24.

Mattis, Jim und Kori Schake. „A Great Divergence?“ Warriors \& Citizens: American Views of Our Military. Hg. Kori Schake und Jim Mattis. Stanford: Hoover Institution Press, 2016. 1-20.

Melley, Timothy. „Zero Dark Democracy“. Narrating 9/11: Fantasies of State, Security, and Terrorism. Hg. John N. Duvall und Robert P. Marzec. Baltimore: Johns Hopkins University Press, 2015. 17-39.

Meyer, Thomas. „Parallelgesellschaft und Demokratie“. Der demokratische Nationalstaat in den Zeiten der Globalisierung: Politische Leitideen für das 21. Jahrhundert. Festschrift zum 80. Geburtstag von Iring Fetscher. Hg. Marcus Llanque, Herfried Münkler und Clemens Stepina. Berlin: de Gruyter, 2002. 193-229.

Micus, Matthias und Franz Walter. „,Parallelgesellschaften“ erleichtern den Übergang in die Mehrheitsgesellschaft: Mangelt es an ,Parallelgesellschaften'?“ Zuwanderung und Integration 4 (2006). https://www.buergerundstaat.de/4_06/parallel.htm (24. November 2020).

Mittell, Jason. Complex TV: The Poetics of Contemporary Television Storytelling. New York: New York University Press, 2015.

Owens, Mackubin Thomas. „Is Civilian Control of the Military Still an Issue“. Warriors \& Citizens: American Views of Our Military. Hg. Kori Schake and Jim Mattis. Stanford: Hoover Institution Press, 2016. 69-96.

Poplin, Cody und Benjamin Wittes. „Public Opinion, Military Justice, and the Fight against Terrorism Overseas“. Warriors \& Citizens: American Views of Our Military. Hg. Kori Schake und Jim Mattis. Stanford: Hoover Institution Press, 2016. 143-60.

Proctor, Robert N. und Londa Schiebinger (Hg.). Agnotology: The Making and Unmaking of Ignorance. Stanford: Stanford University Press, 2008.

Ricks, Thomas. „The Widening Gap Between Military and Society“. The Atlantic Monthly (July 1997). https://www.theatlantic.com/magazine/archive/1997/07/the-widening-gapbetween-military-and-society/306158/ (24. November 2020).

Takaki, Ronald. Double Victory: A Multicultural History of America in World War II. New York: Black Bay Books, 2000.

Thomson, Andrew. Outsourced Empire: How Militias, Mercenaries, and Contractors Support US Statecraft. London: Pluto Press, 2018.

The Unit. CBS, 2006-2009.

Wanzo, Rebecca. The Suffering Will Not Be Televised: African American Women and Sentimental Political Storytelling. Albany: SUNY, 2009.

Young, Cynthia. „Black Ops: Black Masculinity and the War on Terror“. American Quarterly 66.1 (2014): 35-67. 
